\title{
MgAl Mixed Oxide Derived Alkali-free Hydrotalcite for Transesterification of Waste Cooking Oil to Biodiesel
}

\author{
Nur Fazira Edlina, I., Nazrizawati, A.T.* Erma Hafiza, I@A.Z and Noraini, H. \\ Department of Chemistry and Environment, Faculty of Applied Sciences \\ Universiti Teknologi MARA, Shah Alam, Selangor, Malaysia
}

\begin{abstract}
The heterogeneous catalyst, MgAl hydrotalcite (MgAl HT) was synthesised via alkali-free method spanning from 4:1 to 2:1 ratio of $\mathrm{Mg}$ and $\mathrm{Al}$ respectively and underwent subsequent calcination process at $450^{\circ} \mathrm{C}$ for $3 \mathrm{~h}$. The diffraction patterns of MgAl HT indicated the high crystalline structure was obtained. The increasing of the reflection intensity and the sharpness of diffraction lines were seen with the increasing of $\mathrm{Mg}: \mathrm{Al}$ ratio. Calcination has removed the carbonates and hydroxyl layers, thus left only the mixed oxide of $\mathrm{MgO}$ and $\mathrm{Al}_{2} \mathrm{O}_{3}$ as proven by XRD, SEM, EDX and FTIR. This catalyst was used in the transesterification reaction with Waste Cooking Oil (WCO) as feedstock for the production of biodiesel. WCO underwent a pretreatment process to remove the impurities and moisture content. Acid-base titration was performed to determine the acid value and percentage of Free Fatty Acid (\%FFA). The FFA content was 0.073\% (less than 1\%), hence transesterification reaction has been proceeded without before esterification process using methanol to oil ratio 30:1 for $24 \mathrm{~h}$. Results show high percentage yield of biodiesel in 5 wt\% 3:1 MgAl (87.23\%) compared to 84.01\% yield in 5 wt\% 4:1 catalyst and only 79.23\% yield with 5 wt\% 2:1 catalyst.
\end{abstract}

Keywords: MgAl hydrotalcite; alkali-free; catalyst; transesterification; waste cooking oil

\section{INTRODUCTION}

The exhaustion of petroleum nowadays rising concern for the world to find an alternative way to overcome this problem. Bio-based fuel is one of the alternative fuel resources which is biodiesel. Biodiesel molecules consist of fatty acid methyl ester in its chemical structure. It has advantages such as biodegradable and renewable resources, thus making it as an alternative fuel to traditional petroleum diesel. Biodiesel can be produced from several natural and renewable sources such as vegetable oil like palm, rapeseed, soybean, coconut, sunflower, and canola oil etc. (A.Tajuddin et al., 2018; Ullah et al., 2015). Due to the cost of the raw materials are quite high; therefore, waste cooking oil (WCO) is a suitable raw material to reduce the high cost of biodiesel. This research is significant to increase the rate of diesel production based on price and availability. Also, biodiesel has many advantages compared to biodegradable petroleum diesel, renewable sources and low content of sulphur (Kumar et al., 2018; Wilson and Lee, 2016; Aransiola et al., 2014).

Biodiesel is synthesised commonly by transesterification reaction from renewable sources reacts with common alcohol (methanol) in the presence of catalysts. $\mathrm{Mg}-\mathrm{Al}$ hydrotalcite is one of the catalysts that play a vital role in the transesterification process. The general formula for hydrotalcite is $\left[\mathrm{M}^{2+}{ }_{(1-\mathrm{x})} \mathrm{M}^{3+}{ }_{\mathrm{x}}(\mathrm{OH}) 2\right]^{\mathrm{x}+(}\left(\mathrm{A}_{\mathrm{x}} / \mathrm{n}\right)^{\mathrm{n}-} \cdot \mathrm{yH}_{2} \mathrm{O}$ (Ibrahim et al., 2017). The hydrotalcite is also called as layered double hydroxides (LDH) due to its two-dimensional brucites like structure $\left(\mathrm{Mg}(\mathrm{OH})_{2}\right)$ with $\mathrm{M}^{2+}$ (divalent metal cations) and $\mathrm{M}^{3+}$ (trivalent metal cations). In the interlayer space, there is $\mathrm{A}^{\mathrm{n}-}$ which acts as a counter anion to balance the residual positive charges of hydroxides layer comes from the isomorphous substitution of $\mathrm{M}^{2+}$ by $\mathrm{M}^{3+}$ (Reyero et al., 2013). Hydrotalcites (HT) have two representative properties due to its unique properties which can capture and exchange organic and inorganic anions and memory 
effect (Mishra et al., 2018; Takehira et al., 2017; Lee et al., 2016).

$\mathrm{Mg} / \mathrm{Al}$ hydrotalcite is depicted as a raw material for hightemperature insulation porous ceramics for two reasons, the loss of weight during its thermal decomposition results in a large number of pores, and it induces aluminiummagnesium spinel $\left(\mathrm{MgAl}_{2} \mathrm{O}_{4}\right)$ formation (Salomão et al., 2011). Hydrotalcites is applied in various applications which are as ion exchangers, adsorbents, $\mathrm{CO} 2$ capture and carrier of bioactive molecules (Kikhtyanin et al., 2016). The most important part that we are going to investigate is its role as a catalyst, and catalyst support due to its high surface area, structural stability, and phase purity (Wiyantoko et al., 2015). Also, by using the di- and trivalent salts, the preparation of hydrotalcite is simple and most importantly is its lower cost of production (Petrolini et al., 2017).

Hydrotalcite is a type of heterogeneous catalyst, and it has many advantages over a homogenous catalyst which are catalyst reusability, high purity by-products, separation and purification more convenient, no neutralisation step required and catalyst recoverability (Jing et al., 2019; Lam et al., 2010). Furthermore, the heterogeneous catalyst should have high selectivity for the formation of the desired product and produces a high yield (Creasey et al., 2014; Issariyakul and Dalai, 2014). In biodiesel production, when the homogenous catalyst is used, it needs multi-steps of production and purification because such catalyst cannot tolerate with free fatty acids (FFA) and moisture (Baroi and Dalai, 2013). Hence, it will lead to the high cost of refined feedstocks results in a high price of biodiesel compared to petrol diesel (Tajuddin et al., 2016).

Most synthetic HTs/LDHs are prepared via coprecipitation method in basic conditions, which results in the entrainment of residual alkali (Creasey et al., 2015; Creasey et al., 2014). Also, due to its propensities to produce soap formation and mono- and di-glycerides during transesterification, it will cause separation and purification problem. To overcome this drawback, alkali-free LDHs has been introduced and applied in this study.

\section{MATERIALS AND METHOD}

\section{A. Catalyst Synthesis}

MgAl LDHs were prepared by alkali-free coprecipitation method (A.Tajuddin et al., 2018). Solution A has been prepared by adding $19.20 \mathrm{~g} \mathrm{Mg}\left(\mathrm{NO}_{3}\right)_{2} .9 \mathrm{H}_{2} \mathrm{O}$ and $28.12 \mathrm{~g}$ of
$\mathrm{Al}\left(\mathrm{NO}_{3}\right)_{3} \cdot 9 \mathrm{H}_{2} \mathrm{O}$ in $100 \mathrm{~cm}^{3}$ of distilled water in different volumetric flasks. The $\mathrm{Mg}: \mathrm{Al}$ ratio is varied such that $\mathrm{x}+\mathrm{y}=$ 0.15 mol and $x: y=2: 1,3: 1$ and 4:1. The buffer ammonium nitrate $\left(\mathrm{NH}_{3} \mathrm{NO}_{3}\right)$ (0.2 mol) was prepared as solution $\mathrm{B}$ by dissolving $16 \mathrm{~g}$ of $\mathrm{NH}_{3} \mathrm{NO}_{3}$ in $100 \mathrm{~cm}^{3}$ of distilled water. Solution $\mathrm{B}$ has been added dropwise into the solution A until the $\mathrm{pH}$ constant at 7.6-8.o by detecting using a Jenway 3030 $\mathrm{pH}$ meter. The mixture was ageing at $65^{\circ} \mathrm{C}$ while stirring vigorously for $24 \mathrm{~h}$. The catalyst then has been filtered and calcined at $450{ }^{\circ} \mathrm{C}$ for $3 \mathrm{~h}$.

\section{B. Catalyst Characterisation}

Fresh and calcined catalysts were characterised by X-ray Powder Diffraction using X'pert-Pro PANanalytical diffractometer with a $\mathrm{Cu} \mathrm{Ka} \mathrm{X-ray} \mathrm{radiation}(\lambda=1.54056)$ with $2 \theta$ range of $5^{\circ}-80^{\circ}$. The Scanning Electron Microscope (SEM) images (fitted with Energy Dispersive X-Ray Spectroscopy, EDX) were obtained on a JSM-670oF field emission (FE) microscope operating at $15 \mathrm{kv}$. The samples were immobilised on a copper holder using conducting resin and were coated with prior platinum characterisation. The infrared spectra were obtained on Jasco FT-IR-460 spectrometer in range of $4500-900 \mathrm{~cm}^{-1}$ using KBR pellet technique.

\section{Biodiesel Production}

\section{Pre-treatment of waste cooking oil (WCO)}

The pre-treatment process was carried out to remove excess free fatty acid content in waste cooking oil. The activated carbon (0.5 g) was added to $100 \mathrm{ml}$ of waste cooking oil. Then, the mixture was kept in a shaker flask at $150 \mathrm{rpm}$ for $30 \mathrm{~min}$ under room temperature. After that, the oil was filtered before biodiesel production. To determine the free fatty acid (FFA) content, $1 \mathrm{~g}$ of oil was dissolved in $25 \mathrm{~mL}$ of ethanol, and $25 \mathrm{~mL}$ of diethyl ether with a few drops of phenolphthalein was added as an indicator. The titration process was stopped when the solution turned into light pink colour. The acid value (AV) was calculated using the equation:

\section{$\mathrm{AV}(\mathrm{mg} \mathrm{KOH} / \mathrm{g})=\frac{56.1 \times \mathrm{C}(\mathrm{KOH}) \times \mathrm{V}(\mathrm{KOH})}{\text { Mass of oil }}$}


where: 56.1 is the MW of the $\mathrm{KOH}$

$\mathrm{V}(\mathrm{KOH})$ is the volume of $\mathrm{KOH}$ consume during titration $\mathrm{C}(\mathrm{KOH})$ is the concentration of $\mathrm{KOH}$

\section{Transesterification process}

The $25 \mathrm{~g}$ of waste cooking oil was poured in a three-necked round bottom flask equipped with a reflux condenser and cool-water chiller. The WCO was heated at $100^{\circ} \mathrm{C}$ for $30 \mathrm{~min}$ to remove traces of water. A mixture of methanol to oil ratio used for this process was 30:1 with $5 \mathrm{wt} \%$ base catalyst were added, and the reaction was run at $65{ }^{\circ} \mathrm{C}$ at $24 \mathrm{~h}$. The reaction mixture was transferred into the separating funnel. The biodiesel from the upper layer was collected, and the bottom layer of oil was discarded. The rotary evaporator was used to remove the glycerol leaving only biodiesel completely. The final product which is biodiesel was characterised by using Gas Chromatography (Agilent Technologies 6890N) equipped with Flame Ionization Detector (FID) and 30m $\mathrm{x}$ $250 \mu \mathrm{m} \mathrm{HP} 5$-MS capillary column. The injection port was furnished with split mode (40:1) with $250{ }^{\circ} \mathrm{C}$ injection port temperature. The column temperature was initially set at $100{ }^{\circ} \mathrm{C}$ and increased until $290{ }^{\circ} \mathrm{C}$ at $40{ }^{\circ} \mathrm{C} \mathrm{min}-1$. The carrier gas (nitrogen) flow was $30 \mathrm{ml} \mathrm{s}^{-1,}$ and the detector temperature was fitted at $250{ }^{\circ} \mathrm{C}$.

\section{RESULT AND DISCUSSION}

\section{A. Catalyst Characterisation}

The successful synthesis of alkali-free MgAl HTs with molar ratios spanning 2.0-4.0 was performed by powder XRD, EDX, SEM and FTIR analyses. The phase composition of fresh and calcined MgAl HTs was first monitored by XRD. Definite crystalline phases were observed for fresh catalyst (Figure 1a), attributing to the reflections of $2 \theta=11.6^{\circ}, 23.4^{\circ}, 35.0^{\circ}, 39.6^{\circ}$, $47.1^{\circ}, 61.1^{\circ}$, and $61.8^{\circ}$ which associated to MgAl HTs (Wang et al., 2016). The intensity of basal spacing $d(003)$ is increased with the ratio shows the more crystalline structure is obtained at a higher $\mathrm{Mg}$ : $\mathrm{Al}$ composition. Decomposition occurred during the calcination process resulting in the formation of $\mathrm{MgO}$ periclase phases as can be seen in Figure 1b. The XRD diffraction patterns also confirmed the removal of HT layers as the basal spacing of d(003) and d(009) are collapsed (Ibrahim et al., 2017). The same diffraction pattern is portrayed by (Bankauskaite and Baltakys, 2015). No reflections of the $\mathrm{MgAlO}$ and $\mathrm{MgAlCO}_{3}$ were observed in the diffraction patterns except $\mathrm{MgO}$ similar as reported by (Chen et al., 2016).
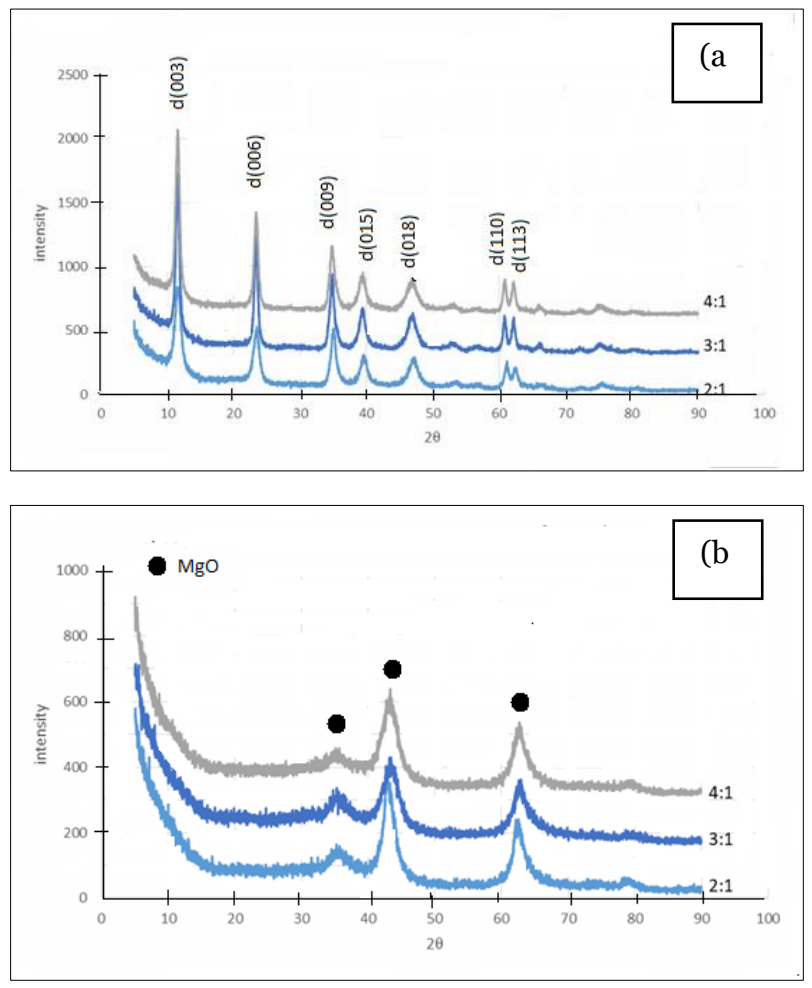

Figure 1. The XRD patterns of fresh (a) and calcined (b) $\mathrm{MgAl}$ HTs with ratio spanning from 2:1 to 4:1, respectively

The pure HTs were further characterised by EDX spectroscopy. Figure 2a, b and $\mathrm{c}$ of the EDX spectra confirmed the presence of $\mathrm{Mg}, \mathrm{Al}$ and $\mathrm{O}$ in MgAl HTs catalyst and no other impurities were detected. Results on weight \% and atomic \% of each element are tabulated in Table 1. Data shows the incorporation of $\mathrm{Mg}: \mathrm{Al}$ is associated with the synthesised ratio. As the ratio of $\mathrm{Mg}$ to $\mathrm{Al}$ is increased, the inclusion of $\mathrm{Mg}$ is observed in the HT framework as both weight and atom \% are substantially increased.

Fig. 3a-c presents the SEM images of MgAl HTs at a different synthesised ratio. A layered crystalline structure with irregular edges is observed here (K. Kaul et al., 2017). As the ratio of $\mathrm{Mg}$ to $\mathrm{Al}$ increased, the catalysts are homogenously grown without aggregation has been observed (Jing et al., 2019), indicating proper incorporation of $\mathrm{Mg}^{2+}$ and $\mathrm{Al}^{3+}$ during coprecipitation process. This further demonstrated that crystallinity formation of HTs improved with the ratio as previously proven by XRD. In this study, the calcined HTs were subsequently characterised by FTIR to identify the functional group present. Table 2 shows the three 
main characteristic band and the wavelength number of $\mathrm{Mg} / \mathrm{Al}$ hydrotalcite at a different ratio. The strong and broad absorption band at $3445.37 \mathrm{~cm}^{-1}$ is correlated to $\mathrm{O}-\mathrm{H}$ stretching vibrations present in the interlayer of catalyst. The C-O vibration appeared around $1412 \mathrm{~cm}^{-1}$ affirmed the interaction of the metal with unidentate carbonate (Chen et al., 2016; Li and Guo, 2015). The AlO deformation and Mg$\mathrm{O}$ translation were found later in the region wavelength around 816-854 $\mathrm{cm}^{-1}$ (Fahami and Beall, 2016; Tittabut and Trakarnpruk, 2008).
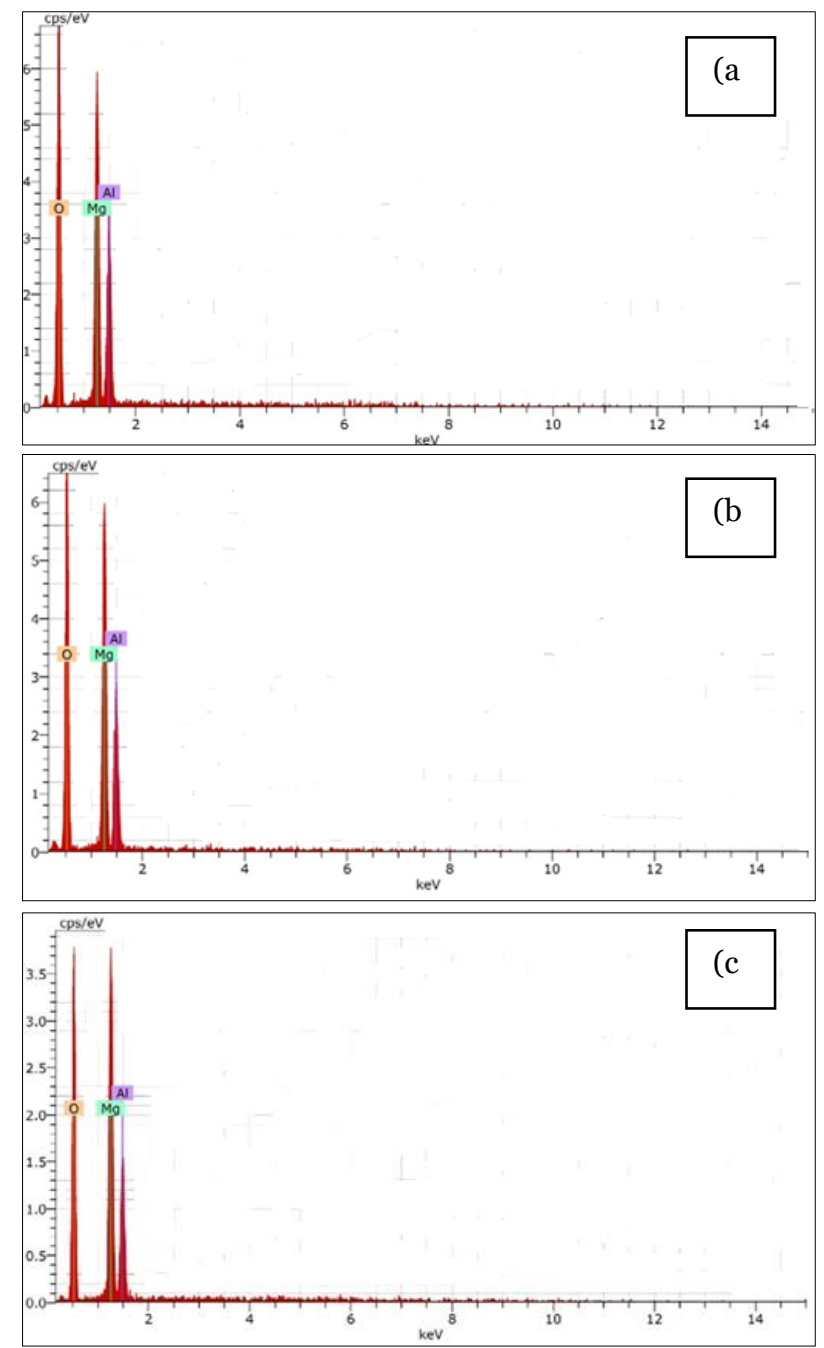

Figure 2. The EDX spectra of MgAl HTs catalyst on ratio 2:1(a), 3:1(b) and 4:1(c)

Table 1. Weight and atomic per cent of each element in $\mathrm{MgAl}$ HTs obtained by EDX spectroscopy

\begin{tabular}{lllc}
\hline $\begin{array}{l}\mathrm{Mg} / \mathrm{Al} \\
\text { ratio }\end{array}$ & Element & Weight \% & Atomic \% \\
\hline & Oxygen & 57.89 & 68.55 \\
$2: 1$ & Magnesium & 24.31 & 18.95 \\
& Aluminium & 17.80 & 12.50 \\
\hline
\end{tabular}

\begin{tabular}{llll} 
& Oxygen & 57.55 & 68.19 \\
3:1 & Magnesium & 25.67 & 20.02 \\
& Aluminium & 16.78 & 11.79 \\
\hline \multirow{2}{*}{ 4:1 } & Oxygen & 54.99 & 65.84 \\
& Magnesium & 28.28 & 22.29 \\
& Aluminium & 16.73 & 11.88 \\
\hline
\end{tabular}
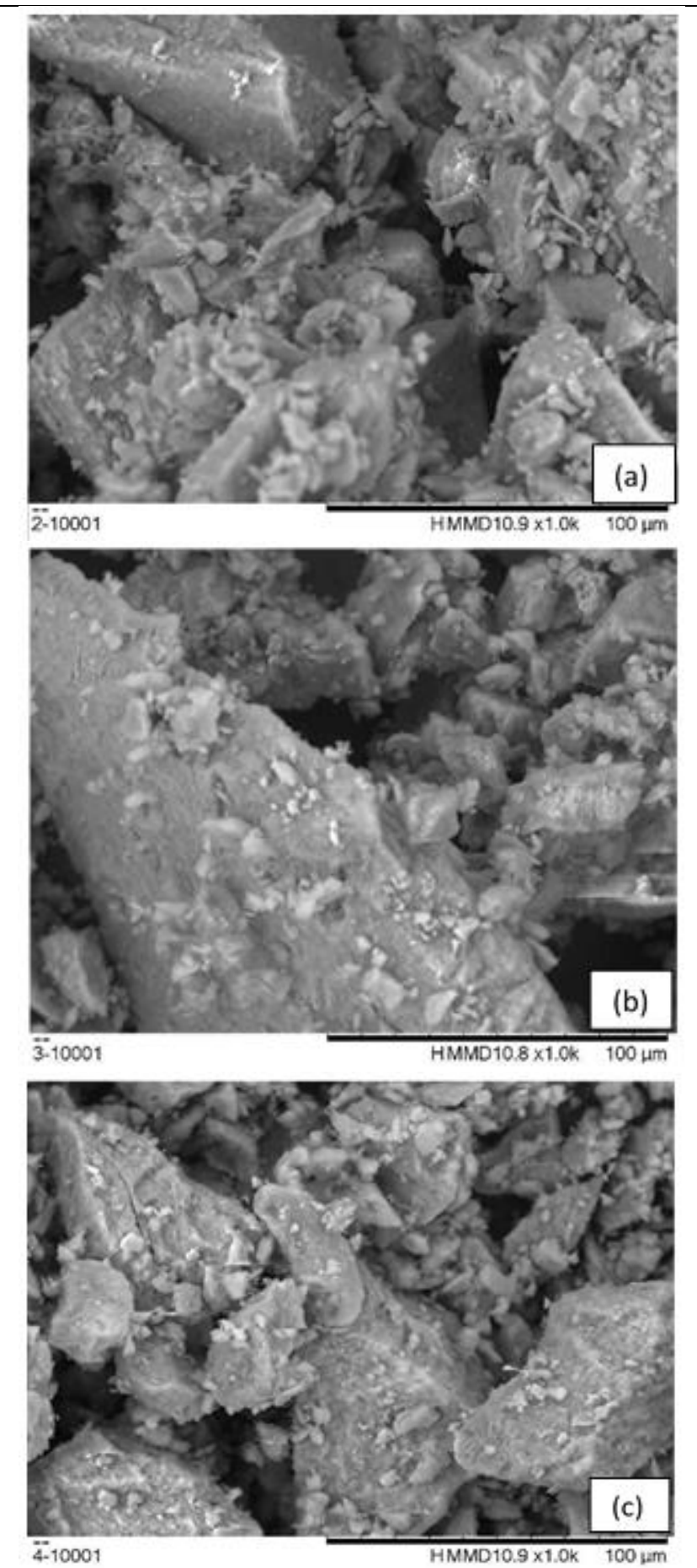

Figure 3. SEM images of MgAl HT at different ratio; 2:1 (a), 3:1(b) and 4:1 (c) 
Table 2. Comparison of data infrared spectra at different $\mathrm{Mg} / \mathrm{Al}$ hydrotalcite ratio

\begin{tabular}{lccc}
\hline \multicolumn{4}{c}{ Wavelength number } \\
\hline $\begin{array}{l}\text { Characteristic } \\
\text { band }\end{array}$ & $\mathrm{Mg} / \mathrm{Al} \mathrm{2:1}$ & $\mathrm{Mg} / \mathrm{Al} 3: 1$ & $\mathrm{Mg} / \mathrm{Al}$ 2:1 \\
\hline $\begin{array}{l}\text { O-H stretching } \\
\text { Vibration }\end{array}$ & 3469.23 & 3445.04 & 3445.37 \\
\hline $\begin{array}{l}\mathrm{C}-\mathrm{O} / \mathrm{C}=\mathrm{O} \\
\text { vibration }\end{array}$ & 1412.47 & 1412.18 & 1412.08 \\
\hline $\begin{array}{l}\text { Al-O/Mg-O } \\
\text { vibration }\end{array}$ & 816.25 & 851.95 & 854.41 \\
\hline
\end{tabular}

\section{B. Biodiesel Production}

WCO was converted into biodiesel via transesterification process in the presence of $\mathrm{MgO}$ from calcined catalyst to produce methyl esters and glycerol as the by-product. Previously, WCO underwent a pre-treatment process by centrifuged and heated to remove any traces and moisture content (Javidialesaadi and Raeissi, 2013). Table 3 shows the acid value and FFA\% before and after pre-treatment process. Results show the FFA value is less than 1\% (0.0730\%) indicated no esterification process requires before transesterification reaction.

Table 3. Acid value and percentage of free fatty acid in WCO before and after pre-treatment process

\begin{tabular}{lcc}
\hline & \multicolumn{2}{c}{ Value } \\
\hline Parameter & $\begin{array}{l}\text { Titration of WCO } \\
\text { before heating }\end{array}$ & $\begin{array}{c}\text { Titration of WCO } \\
\text { after heating }\end{array}$ \\
\hline Acid value, & 0.90 & 0.73 \\
mgKOH/g & & \\
\hline
\end{tabular}

\begin{tabular}{lll}
\hline Free fatty acid & 0.0898 & 0.0730 \\
(FFA) content (\%) & & \\
\hline
\end{tabular}

Gas Chromatography was used to analyse the fatty acid methyl ester (FAME) contents in biodiesel. To determine the presence of FAME in biodiesel, the retention time of the sample was compared with the retention time of standard FAME. Table 4 shows the retention time of individual FAME standard and biodiesel samples from the chromatogram. Results show the retention time for both standard and samples were slightly different due to several factors such as polarity of the FAME and volatility of the compound (Girish et al., 2013).

Methyl laurate was eluted first due to it is less non-polar compared to methyl stearate, which is more non-polar and eluted at a longer time. Apart than that, methyl laurate is the most volatile compound and has the lowest boiling point, thus it eluted at a shorter time compared to other compounds (García et al., 2012). The biodiesel was produced by the reaction of 30:1 methanol/oil with 5 wt\% of $\mathrm{MgAl}$ hydrotalcite in the transesterification process. The yield of biodiesel for 2:1, 3:1 and 4:1 $\mathrm{Mg}: \mathrm{Al}$ ratio were $79.23 \%, 87.23 \%$ and $84.01 \%$ respectively. Figure 4 shows the GC chromatogram of the biodiesel at 3:1 ratio with the highest yield of $87.23 \%$.

Table 4. Average of retention time of individual FAME on standard and biodiesel samples from WCO at a concentration of $100 \mathrm{ppm}$

\begin{tabular}{ccc}
\hline \multirow{2}{*}{ FAME } & \multicolumn{2}{c}{ Retention time, min } \\
\cline { 2 - 3 } & Standard & Samples \\
\hline $\begin{array}{c}\text { Methyl } \\
\text { laurate }\end{array}$ & 1.941 & 1.948 \\
\hline $\begin{array}{c}\text { Methyl } \\
\text { myristate }\end{array}$ & 2.711 & 2.715 \\
\hline $\begin{array}{c}\text { Methyl } \\
\text { palmitate }\end{array}$ & 4.295 & 4.263 \\
\hline $\begin{array}{c}\text { Methyl } \\
\text { linoleate }\end{array}$ & 6.823 & 6.815 \\
\hline $\begin{array}{c}\text { Methyl } \\
\text { stearate }\end{array}$ & 7.431 & 7.382 \\
\hline
\end{tabular}

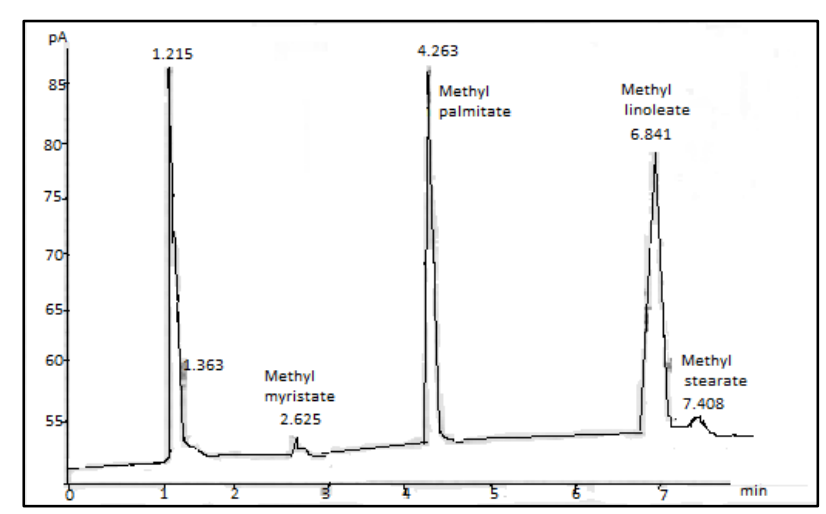

Figure 4 GC chromatogram of biodiesel from WCO with the 5 wt\% catalyst loading of 3:1 ratio of $\mathrm{Mg}: \mathrm{Al}$ and 30:1 methanol/oil ratio.

\section{CONCLUSION}

MgAl HTs catalyst was successfully synthesised via the alkalifree method and further underwent a calcination process. The XRD confirmed the successful synthesised of pure and calcined HTs. HTs compound possesses only $\mathrm{Mg}, \mathrm{Al}$ and $\mathrm{O}$ atom as proven by EDX. The pronounced characteristic 
bands observed by FTIR further affirmed the characteristic of HTs. The SEM shows irregular edges of HTs images, and the coprecipitation shown better growth on a higher $\mathrm{Mg}$ to $\mathrm{Al}$ ratio. The transesterification reaction was performed by added 5 wt\% catalyst loading of 3:1 ratio of $\mathrm{Mg}: \mathrm{Al}$ with 30:1 methanol/oil ratio has produced $87.23 \%$ biodiesel yield.

\section{ACKNOWLEDGEMENT}

The authors would like to thank the Research Management Centre (RMC), Universiti Teknologi MARA (UiTM) for financing this project under FRGS fund (600-IRMI/FRGS $5 / 3(403 / 2019)$.

\section{REFERENCES}

Ahmad Tajuddin, N, Manayil, JC, Isaacs, MA, Parlett, CMA, Lee, AF \& Wilson, K 2018, 'Alkali-free Zn-Al layered double hydroxide catalysts for triglyceride transesterification', Catalysts, vol. 8, no. 12, pp. 1-11.

Aransiola, EF, Ojumu, TV, Oyekola, OO, Madzimbamuto TF \& Ikhu-Omoregbe, DIO 2014, 'A review of current technology for biodiesel production: State of the art', Biomass and Bioenergy, vol. 61, pp. 276-297.

Bankauskaite, A \& Baltakys, K 2015, 'Thermal, texture and reconstruction properties of hydrotalcites substituted with $\mathrm{Na}+$ or $\mathrm{K}+$ ions', Journal of Thermal Analysis and Calorimetry, vol.121, no. 1, pp. 227-233.

Baroi, C \& Dalai, AK 2013, 'Simultaneous esterification, transesterification and chlorophyll removal from green seed canola oil using solid acid catalysts', Catalysis Today, vol. 207, pp. 74-85.

Chen, CR, Zeng, HY, Xu, S, Liu, XJ, Duan, HZ \& Han, J 2016, 'Preparation of mesoporous material from hydrotalcite/carbon composite precursor for chromium(VI) removal', Journal of the Taiwan Institute of Chemical Engineers, vol 67, pp 29-44.

Creasey, JJ, Chieregato, A, Manayil, JC, Parlett, CMA, Wilson, K \& Lee, AF 2014, 'Alkali- and nitrate-free synthesis of highly active $\mathrm{Mg}-\mathrm{Al}$ hydrotalcite-coated alumina for FAME production', Catalysis Science and Technology, vol. 4, no.3, pp. 861-870.

Creasey, JJ, Parlett, CMA, Manayil, JC, Isaacs, MA, Wilson, K \& Lee, AF 2015, 'Facile route to conformal hydrotalcite coatings over complex architectures: A hierarchically ordered nanoporous base catalyst for FAME production', Green Chemistry, vol. 17, no. 4, pp. 2398-2405.
Fahami, A \& Beall, GW 2016, 'Structural and morphological characterisation of MgO.8AlO.2(OH)2ClO.2 hydrotalcite produced by mechanochemistry method', Journal of Solid State Chemistry, vol.233, pp. 422-427.

García, SCM, Gómez, RSM, De Lima Da Silva, N, De Camargo, CL, Kieckbusch, TG and Wolf MacIel, MR 2012, 'Measurements of normal boiling points of fatty acid ethyl esters and triacylglycerols by thermogravimetric analysis', Fuel, vol. 92, no.1, pp. 158-161.

Girish, N, Niju, SP, Meera Sheriffa Begum, KM \& Anantharaman, N 2013, 'Utilisation of a cost effective solid catalyst derived from natural white bivalve clam shell for transesterification of waste frying oil', Fuel, 111, pp. 653-658.

Ibrahim, EH, Ahmad Tajuddin, N. \& Hamzah, N 2017, 'Synthesis and Characterisation of Mg-Al Layered Double Hydroxide for Transesterification of Waste Cooking Oil to Bio- diesel : Effect of Mg / Al Ratio, International Journal of Engineering \& Technology, vol. 7, no4.14, pp. 154-57.

Issariyakul, T \& Dalai, AK 2014, 'Biodiesel from vegetable oils', Renewable and Sustainable Energy Reviews, vol. 31, pp. 446-471.

Javidialesaadi, A \& Raeissi, S 2013, 'Biodiesel Production from High Free Fatty Acid-Content Oils: Experimental Investigation of the Pretreatment Step', APCBEE Procedia, vol. 5, pp. 474-478.

Jing, C, Zhang, Q, Liu, X, Chen, Y, Wang, X, Xia, L, Zeng, H, Wang, D, Zhang, W \& Dong, F 2019, 'Design and fabrication of hydrotalcite-like ternary $\mathrm{NiMgAl}$ layered double hydroxide nanosheets as battery-type 
electrodes for high-performance supercapacitors', RSC Advances, Royal Society of Chemistry, vol. 9, no. 17, pp. 9604-9612.

Kikhtyanin, O, Lesnik, E \& Kubička, D 2016, 'The occurrence of Cannizzaro reaction over Mg-Al hydrotalcites', Applied Catalysis A: General, vol. 525, pp. 215-225.

Kumar, R, Enjamuri, N, Shah, S, Al-Fatesh, AS, BravoSuárez, JTM \& Chowdhury, B 2018, 'Ketonization of oxygenated hydrocarbons on metal oxide based catalysts', Catalysis Today, vol. 302, pp. 16-49.

Lam, MK, Lee, KT \& Mohamed, AR 2010, 'Homogeneous, heterogeneous and enzymatic catalysis for transesterification of high free fatty acid oil (waste cooking oil) to biodiesel: A review.', Biotechnology Advances, vol. 28, no. 4, pp. 500-18.

Lee, G, Kang, JY, Yan, N, Suh, YW \& Jung, JC 2016, 'Simple preparation method for $\mathrm{Mg}-\mathrm{Al}$ hydrotalcites as base catalysts', Journal of Molecular Catalysis A: Chemical, vol. 423, pp. 347-355.

$\mathrm{Li}, \mathrm{M} \&$ \&uo, Q 2015, "The preparation of the hydrotalcite-based composite phase change material', Applied Energy, vol.156, pp. 207-212.

Mishra, G, Dash, B \& Pandey, S 2018, 'Layered double hydroxides: A brief review from fundamentals to application as evolving biomaterials', Applied Clay Science, vol. 153, pp. 172-186.

Petrolini, DD, Urquieta-González, EA, Pulcinelli, SH, Santilli, CV \& Martins, L 2017 'Emulsion-mediated synthesis of hierarchical mesoporous-macroporous Al-Mg hydrotalcites', Microporous and Mesoporous Materials, vol. 240, pp. 149-158.

Reyero, I, Arzamendi, G \& Gandía, LM 2013, 'Hydrotalcites as catalysts and catalysts precursors for the synthesis of biodiesel', Key Engineering Materials, vol. 571, pp. 1-26.

Salomão, R, Milena, LM, Wakamatsu, MH \& Pandolfelli, VC 2011, 'Hydrotalcite synthesis via coprecipitation reactions using $\mathrm{MgO}$ and $\mathrm{Al}(\mathrm{OH})_{3}$ precursors', Ceramics International, vol. 37, no. 8, pp. 3063-3070.

Tajuddin, NA, Lee, AF \& Wilson, K 2016, ‘6 -
Production of biodiesel via catalytic upgrading and refining of sustainable oleaginous feedstocks', Handbook of Biofuels Production, pp. 121-164.

Takehira, K 2017, 'Recent development of layered double hydroxide-derived catalysts -Rehydration, reconstitution, and supporting, aiming at commercial application', Applied Clay Science, vol. 136, pp. 112141.

Tittabut, T \& Trakarnpruk, W 2008, 'Metal-Loaded MgAl Oxides for Transesterification of Glyceryl Tributyrate and Palm Oil', American Chemical Society, vol. 47, no. 7, pp. 2176-2181.

Ullah, F, Dong, L, Bano, A, Peng, Q \& Huang, J 2015, 'Current advances in catalysis toward sustainable biodiesel production', Journal of the Energy Institute, vol. 89, no. 2, pp. 1-11.

Wilson, K \& Lee, AF, 2016, 'Catalyst design for biorefining.', Philosophical transactions. Series A, Mathematical, physical, and engineering sciences, vol. 374, no. 2061, pp. 1-24.

Wiyantoko, B, Kurniawati, P, Purbaningtias, TE \& Fatimah, I 2015, 'Synthesis and Characterisation of Hydrotalcite at Different $\mathrm{Mg} / \mathrm{Al}$ Molar Ratios', Procedia Chemistry, vol. 17, pp. 21-26. 